\title{
520 生活支援機器の安全性評価に関する検討
}

\section{Examination of Safety Evaluation Method of Life Support Instrument}

\author{
○正 伊藤 安海 (長寿研) 正 最上 和生 (科警研) \\ 正 根本 哲也 (長寿研) 正 松浦 弘幸 (長寿研)
}

\begin{abstract}
Yasumi ITOH, National Institute for Longevity Sciences, 36-3, Gengo, Morioka, Obu, Aichi Kazunari MOGAMI, National Research Institute of Police Science Tetsuya NEMOTO, National Institute for Longevity Sciences Hiroyuki MATUURA, National Institute for Longevity Sciences
\end{abstract}

Key Words : Impact Load, Life Support Instrument, Safety Evaluation Method, Buffer Material, Load Cell

\section{1. 暂霎}

ロボティクス技術の発達に伴い，インテリジェントな機 能を有する生活支援機器が開発されつつある.それに伴い, 作動中の支援機器との接触による受傷事故といった, 新た な問題の発生が㤡念されている.

しかし，人体損傷の観点から外力（衝撃荷重）の大きさ を評価する場合, 作用する力の平均值, 最大值, 作用時間 など考慮すべきパラメータが複数存在し，定量化が困難で ある.さらに，骨折，脳震盪など対象とする損傷毎に評価 手法が異なるため, 自動車乗員の安全性評価に利用されて いる衝慗加速度の評価法（HIC，SI）などの確立された評 価手法をそのまま利用できない事故形態も多い.

また，衝擊荷重による人体損傷評価法は，殺人未遂・傷 害事件における殺意の有無を明らかにする目的で，警察に おいても従来から熱心に研究されてきた (1)-(3). その結果,

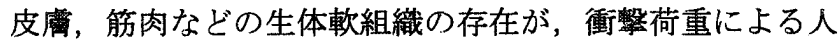
体損傷に大きな影響を及ぼすことが明らかとなってきた。

そこで本研究では，支援機器との接触により発生する衝 慗荷重を計測する際に使用する緩衝材 (生体軟組織代用物) を選定する目的で, 数種類の生体軟組織および緩衝材の衝 撃吸収特性を調査し比較を行った。

また，車いすなど従来から利用されている生活支援機器 の事故形態調查結果によると，部材の老朽化による破損が 原因となった事故の発生が, 毎年確認されている. 当然, JIS（T9201，T9203）により手動・電動車いすの耐久性, 耐 衝慗性などの安全基準は規定されているが，構造部材とし て歴史の浅い, マグネシウム, チタンなどの軽金属合金は 疲労特性も十分解明されておらず，安全基準をクリアーし ていたとしても，破損事故の危険性は残されている.

そこで，本研究では，アルミニウム合金およびマグネシ ウム合金の二朝疲労試験結果 ${ }^{(4)-(6)}$ 考察し，現在の酎久性 評価法に対する問題点を明らかにした。

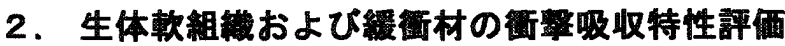

2・1 实騙材料および实験方法本実験に用いた生体軟 組織および緩衝材は Table 1 に示すとおりである.実験は 3 個のロードセル（LC-2TN : 共和電業）で支えられた鉄板の
上に生体軟組織又は緩衝材を膡き，乙の上に，規定した高 さ $(0.25,0.5,0.75,1.0 \mathrm{~m})$ から $500 \mathrm{~g}$ の鍾を落下させる形 式で行った. 錘の衝突速度は, 実験を真横から高速度ビデ オカメラ（メモリカム: NAC）で撮影し，画像解析するこ とによって求めた. なお, 錘には Fig.1 に示すように, 予 め速度計測部位にターゲットマークを貼り付けておいた。

Table 1 Test material

(a) Soft tissue

\begin{tabular}{|c|c|}
\hline & Thickness [mm] \\
\hline Pork tenderloin & 31.5 \\
\hline Pork loin & 57.0 \\
\hline Beef tenderloin & 25.0 \\
\hline Chicken breast & 21.0 \\
\hline Chicken thighs & 11.4 \\
\hline Left arm (human body) & 64.1 \\
\hline Right arm (human body) & 73.9 \\
\hline
\end{tabular}

(b) Buffer material

\begin{tabular}{|c|c|}
\hline & Thickness [mm] \\
\hline Cell sponge & $5,10,20,30$ \\
\hline Soft sponge & $5,10,20$ \\
\hline Rubber & $5,10,20$ \\
\hline
\end{tabular}

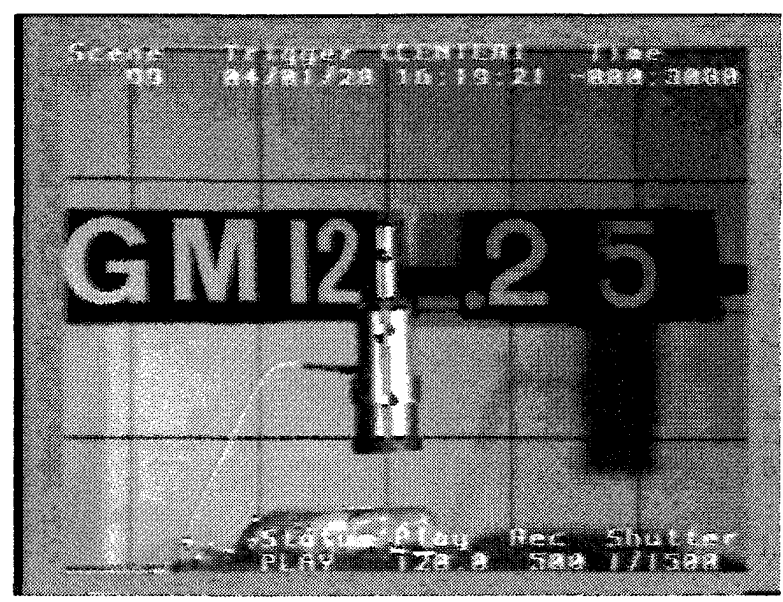

Fig. 1 Photograph of a test situation 
2:2 实跧結果実験の結果, 生体軟組織では, その種 類によらず，錘落下高さと最大衝撃荷重の関係はほぼ同じ 傾きの直線で表されることが明かとなった．また，測定さ れた最大衝撃荷重は生体軟組織の厚さに反比例することも 確かめられた. それに対して, 緩衝材では材質毎に錘落下 高さと最大衝撃荷重の関係が大きく異なっていた.ここで, 3 種類の緩衝材と生体軟組織を比較すると, ゴムは全ての 条件で生体軟組織と大きく異なり，軟質スポンジも錘落下 高さが上昇するに従って生体軟組織の值から大きく外れて しまうが，セルスポンジは全ての条件（錘落下高さ，緩衝 材厚さ）で生体軟組織とほぼ同一の最大衝撃荷重を示すこ とが明かとなった．実験結果の一部を Fig.2 に示す。

\section{3. 生活支援機器材料（轻金属）の二軸麦労特性}

構造材料としての歴史が長く, 疲労特性も十分明かとな っているアルミニウム合金と, 近年構造部材としての使用 が増えてきたマグネシウム合金の二軸疲労試験結果を比較 し, 軽金属材料が複雑な応力状態で使用される場合の危険 性について考察を行った。

\section{3・1 供試村およひ突験方法実験に用いられた試験片} はマグネシウム合金 AZ31B とアルミニウム合金 2024T3 の 厚さは $t=2.5 \mathrm{~mm}$ の板材で, 試験片中央に供試材 生成時の圧延方向を $Y$ 軸として, $Y$ 軸を基準に $\theta=0^{\circ}$ ，長さ $30 \mathrm{~mm}$ の予き裂が入れられたもの である。

疲労試験は二軸負荷荷重比（X軸方向荷重 $P_{x}$ と $Y$ 軸方向荷重 $P_{y}$ の比) $R_{b}=P_{x} / P_{y}$ $=0,0.25,0.5,0.75,1.0$ の正弦波で行われた。 また、 き裂の進展はレーザ一顕微鏡により観察し，長 さの測定を行った.

3-2 实倹結果および考察実験の結果，き 裂進展速度 $\mathrm{d} a / \mathrm{d} N$ と応力拡大係数幅 $\Delta K$ の関係 は，マグネシウム合金，アルミニウム合金共に パリス則に従うものの，アルミニウム合金は二 軸負荷荷重比の影響を受けないのに対し，マグ ネシウム合金は二軸負荷荷重比が僅かに変化し ただけで，き裂進展速度が大きく変化している

(Fig.3)。このような現象は線形破壊力学では 予見されておらず，他の材料においても同様の 現象が存在するのかを, 今後調べる必要がある.

\section{4. 結言}

生活支援機器の安全性評価に関して, 機器 と人体の接触時の安全性, 機器部材の破壊に 対する安全性の見地から検討を行い，以下の 知見が得られた。

1. 生体軟組織の衝撃吸収特性は種類, 部位 によらず，ほぼ一定である。

2. セルスポンジの衝撃吸収特性は生体軟組 織の衝撃吸収特性と非常に良く一致し,

今後, 生活支援機器との接触により人体 が受ける衝撃荷重を測定する際に, 生体 軟組織代用物として使用可能なことが明 かとなった。

3.マグネシウム合金では，これまでの破壊 力学では影響が無いとされてきた，き裂 に平行な応力の変化により, 疲労き裂進
展速度，疲労破壊寿命が大きく変化していた．

4. 近年, 軽量・高強度の材料が数多く開発され, 生活支 援機器の部材としての使用も增えているが, 疲労特性 が十分に解明されておらず, 機器開発時の耐久試験と 僅かに異なる応力環境での使用であっても，推測より 大幅に短い期間で破損に至る危険性があることが明か となった.

\section{文献}

(1) 伊藤安海, The Second Conference on Biomechanics, 日 本実験力学会講演論文集, 4-3, (2002), pp. 21-24.

(2) 伊藤安海, 最上和生, 第 50 回応用物理学関係連合講 演会講演予稿集, (2003), pp. 75.

(3) 伊藤安海, 最上和生, 第 50 回応用物理学関係連合講 演会講演予稿集, (2004), pp. 71.

(4) Y.Itoh, A.Shimamoto, Key Engineering Materials, 270-273, (2004), pp. 1246-1253.

(5) Y.Itoh, A.Shimamoto, Materials Science Forum, 488-489, (2005), pp. 859-864.

(6) Y.Itoh, A.Shimamoto, Key Engineering Materials, (2005), pp. 297-300.

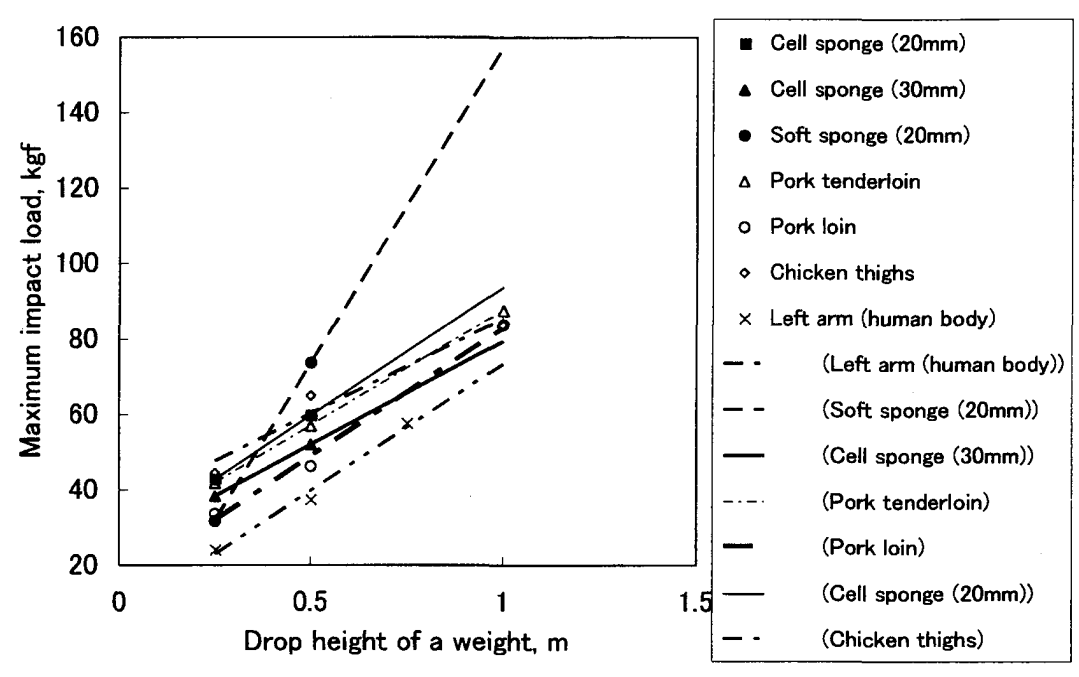

Fig. 2 Relationship between weight drop height and maximum impact load

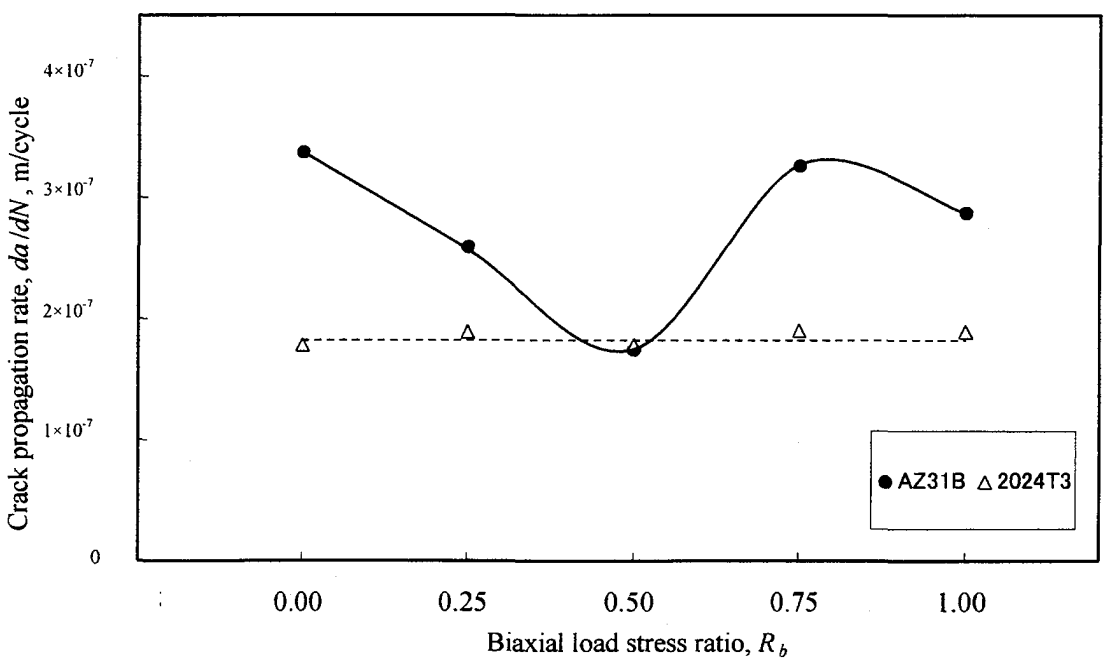

Fig. 3 Relation between crack propagation rate and biaxial load stress ratio. ( $\Delta K_{\mathrm{I}}=7$ (magnesium alloy), $\Delta K_{\mathrm{I}}=15$ (aluminum alloy)) 